\title{
Uterine and Hepatic Gene Expression in Relation to Days Postpartum, Estrus, and Pregnancy in Postpartum Dairy Cows
}

\author{
M. L. Rhoads, ${ }^{1}$ J. P. Meyer, W. R. Lamberson, D. H. Keisler, and M. C. Lucy ${ }^{2}$ \\ Division of Animal Sciences, University of Missouri, Columbia 65211
}

\begin{abstract}
The somatotropic axis consisting of growth hormone, the growth hormone receptor (GHR) insulin-like growth factor (IGF)-I, and IGF binding proteins changes with the stage of lactation and nutrition of the cow and may be 1 mechanism through which lactation and nutrition affect the establishment of pregnancy. The objective of this study was to quantify GHR, IGF-I, and IGF binding protein-2 (IGFBP-2) mRNA in liver and uterine endometrial tissue at 4 stages of lactation $(40,80,120$, and 160 days in milk) and around the time of artificial insemination. Estrus was synchronized with GnRH and $\mathrm{PGF}_{2 \alpha}$, and cows were inseminated $12 \mathrm{~h}$ after estrus. Uterine biopsies were collected immediately before the second injection of $\mathrm{PGF}_{2 \alpha}$ (before estrus), at the initiation of standing estrus, and $4 \mathrm{~d}$ after estrus. Liver biopsies were collected once on $4 \mathrm{~d}$ after estrus. The abundance of GHR, IGF-I, and IGFBP-2 mRNA in liver and uterus was determined by real-time quantitative PCR. The amount of liver IGF-I mRNA was positively correlated with plasma IGF-I concentrations. Cows that became pregnant after AI had more GHR and IGFBP-2 mRNA in their liver than cows that did not become pregnant. There was no effect of DIM or pregnancy status on abundance of uterine mRNA; however, uterine GHR and IGF-I mRNA was most abundant at estrus. In summary, cows at different stages of lactation or with different pregnancy statuses had similar quantities of uterine mRNA. In contrast, liver quantities of mRNA differed relative to pregnancy status. These data provide evidence that liver indices of metabolic state may be indicative of pregnancy success.
\end{abstract}

Key words: growth hormone, insulin-like growth factor-I, estrus, pregnancy

\section{INTRODUCTION}

Nutritional and metabolic stress may be responsible for poor reproductive performance in high milk-produc-

\footnotetext{
Received June 12, 2007.

Accepted September 4, 2007.

${ }^{1}$ Current address: Department of Animal Sciences, University of Arizona, Tucson, AZ 85721.

${ }^{2}$ Corresponding author: LucyM@missouri.edu
}

ing dairy breeds. The biological mechanisms that signal nutritional or metabolic stress to the reproductive system are under investigation. One important mechanism involves the endocrine signals arising from the growth hormone (GH)-IGF system. The GH-IGF system consists of GH, IGF-I, and IGF binding proteins (IGFBP). The GH-IGF system is dynamically regulated during the periparturient period (Kobayashi et al., 1999; Radcliff et al., 2003) and during periods of high milk production (Taylor et al., 2004) or undernutrition (Thissen et al., 1994; Leon et al., 2004). Greater GH and lesser IGF-I concentrations in blood facilitate the high milk production phenotype. This same endocrine state (high GH and low IGF-I) is associated with delayed first ovulation and infertility in dairy cattle (Taylor et al., 2004).

Most of the circulating IGF-I and IGFBP come from the liver; an organ whose endocrine function is directly tied to the nutrition of the cow. During negative energy balance or undernutrition, the liver produces less IGFI and shifts its IGFBP production from IGFBP-3 to IGFBP-2 (McGuire et al., 1995; Rausch et al., 2002; Radcliff et al., 2004). In addition to this hepatic component, the GH-IGF system genes are expressed locally within numerous tissues including those of the reproductive tract (Watson et al., 1999). The GH-IGF system gene products play roles in reproductive processes that ultimately lead to pregnancy. For example, both GH and IGF-I play supportive roles in essential ovarian processes and also improve early embryonic development (Izadyar et al., 1996; Moreira et al., 2002b). Conception rates improved when blood IGF-I concentrations increased after treating lactating dairy cows with bST (Moreira et al., 2002a; Bilby et al., 2006; Starbuck et al., 2006). One hypothesis emerging from these data is that components of the GH-IGF axis (either produced systemically or locally within the reproductive tract) affect the likelihood of conception. It may be possible to change reproductive outcomes in dairy cattle by manipulating the GH-IGF-I axis.

We hypothesized that 1) mRNA expression of GHIGF system genes would change in hepatic and uterine tissue as the cow progressed through the lactation cycle, 2) mRNA expression in the uterus would vary with 
stage of the estrous cycle at tissue collection, and 3) GH-IGF system gene expression would differ after insemination relative to subsequent pregnancy status. The objective of this study, therefore, was to measure IGF-I, GH receptor (GHR), and IGFBP-2 mRNA in uterine tissue around the time of AI at 4 stages of lactation (40 through 160 DIM) and to compare levels of gene expression for cows that became pregnant to those that did not become pregnant.

\section{MATERIALS AND METHODS}

\section{Animals}

This experiment was reviewed and approved by the Institutional Animal Care and Use Committee of the University of Missouri. Multiparous lactating Holstein dairy cows $(\mathrm{n}=33)$ from 41 to 182 DIM were used. Eligible cows had been inseminated either $0(n=27)$, $1(n=5)$, or $2(n=1)$ times before the start of the project. The cows were housed in a concrete-floored free-stall barn at the University of Missouri Foremost Dairy Farm and managed according to the standard operating procedures of the dairy. Cows were milked twice daily and fed a TMR consisting of corn silage, alfalfa hay, alfalfa haylage, ground corn, soybean meal, whole cottonseeds, and a vitamin and mineral premix.

\section{Study Groups}

Cows were divided into 4 groups based on stage of lactation: $40 \mathrm{~d}(46 \pm 4 \mathrm{DIM} ; \mathrm{n}=5), 80 \mathrm{~d}$ (80 \pm 3 DIM; $\mathrm{n}=10), 120 \mathrm{~d}(122 \pm 3$ DIM; $\mathrm{n}=10)$, and $160 \mathrm{~d}(160 \pm$ 3 DIM; $\mathrm{n}=8$ ). Estrous cycles were synchronized with a $\mathrm{PGF}_{2 \alpha}$ injection (25 mg of Lutalyse, Pfizer Inc., New York, NY; i.m.), followed $3 \mathrm{~d}$ later with a GnRH injection (100 $\mu \mathrm{g}$ of Cystorelin, Merial Ltd., Iselin, NJ; i.m.) and $8 \mathrm{~d}$ later with a second $\mathrm{PGF}_{2 \alpha}$ injection (protocol; Borman et al., 2003). Cows were observed for signs of estrus 2 to 3 times daily (30-min observation periods) beginning $1 \mathrm{~d}$ after the second $\mathrm{PGF}_{2 \alpha}$ injection. Cows were inseminated approximately $12 \mathrm{~h}$ after the initiation of standing estrus. Inseminations were performed by the same individual. Table 1 shows timing of treatment and sample collection.

A uterine biopsy was collected when the second $\mathrm{PGF}_{2 \alpha}$ injection was administered. At the same time, ovarian follicles and the corpus luteum (CL) were measured by transrectal ultrasonography (Aloka 500V ultrasound scanner with a 7.5 MHz probe, Aloka Co. Ltd., Tokyo, Japan). At the initiation of standing estrus, the ovarian follicles and the CL were again measured, and a second uterine biopsy was collected (approximately $12 \mathrm{~h}$ before insemination). The third uterine biopsy (and ovarian ultrasound) was performed $4 \mathrm{~d}$ after estrus. Ovarian
Table 1. Treatment and sample collection protocol for dairy cows that were divided into 4 groups based on DIM $(40,80,120$, or 160$)$ and had uterine samples collected before estrus, at estrus, and after estrus $^{1}$

\begin{tabular}{lc}
\hline Activity & Day \\
\hline $\mathrm{PGF}_{2 \alpha}$ injection & -14 \\
$\mathrm{GnRH}_{\text {injection }}$ & -11 \\
Uterine sample collection; $\mathrm{PGF}_{2 \alpha}$ injection & -3 \\
Uterine sample collection (estrus) & 0 \\
Insemination & 0.5 \\
Uterine and liver sample collection & 4 \\
Pregnancy diagnosis & 30 \\
\hline
\end{tabular}

${ }^{1} \mathrm{~A}$ liver sample was also collected after estrus.

ultrasound examinations were used to confirm anticipated changes in gross ovarian morphology (regression of the CL, ovulation, etc.) and were not analyzed further.

Pregnancy was diagnosed by ultrasound $30 \mathrm{~d}$ after estrus, and calving dates were used to confirm pregnancy diagnoses. Body weight and BCS (1- to 5-point scale; $1=$ thin to $5=$ fat) were recorded at estrus, and BCS was also recorded for a second time at pregnancy diagnosis (30 d after estrus). The BCS was measured by 2 individuals, and the scores were averaged. Daily milk production was recorded from the time of the first $\mathrm{PGF}_{2 \alpha}$ injection until pregnancy diagnosis. Average daily milk production was calculated for each cow.

\section{Biopsy and Blood Sampling Procedures}

Uterine Biopsies. Endometrial tissue was collected transcervically from each uterine horn. The vulva and surrounding area were cleansed with an iodine scrub solution and water. The biopsy instrument $(3 \times 450$ $\mathrm{mm}$, semiflexible forceps with a Palmer Jacobs jaw; Richard Wolf Medical Instruments Corporation, Vernon Hills, IL) was covered with a sanitary disposable sheath (Agtech Inc. USA, Manhattan, KS) and inserted into the vagina. The biopsy forceps were positioned at the cervical os, and the sheath was retracted to force the instrument through the end of the sheath. The exposed biopsy forceps were then threaded through the cervix, into the uterine body, and into one of the uterine horns. Endometrial tissue was collected at a location approximately $8 \mathrm{~cm}$ beyond the uterine bifurcation. The collected tissue was placed in a screw-cap microcentrifuge tube and frozen in liquid N. The process was repeated to collect tissue from the opposite uterine horn, and the second tissue sample was frozen in a separate tube. Tissue samples were stored at $-80^{\circ} \mathrm{C}$.

Liver Biopsies. A liver sample was collected from each cow at $4 \mathrm{~d}$ after estrus. Liver samples were collected by needle biopsy as described by Kobayashi et 
Table 2. Oligonucleotide primers and probes and GenBank accession numbers for genes whose mRNA abundance was measured by using reverse transcription-PCR analysis (Taqman assay) ${ }^{1}$

\begin{tabular}{|c|c|c|c|c|}
\hline Gene & $\begin{array}{l}\text { GenBank } \\
\text { number }\end{array}$ & Primer & $\begin{array}{l}\text { Nucleotide } \\
\text { range }\end{array}$ & Sequence \\
\hline Total growth hormone receptor & NM_176608 & Forward & 35 to 55 & GGTATGGATCTCTGGCAGCTG \\
\hline \multirow[t]{2}{*}{ Growth hormone receptor $1 \mathrm{~A}$} & None $^{2}$ & Forward & 158 to 179 & CCAGCCTCTGTTTCAGGAGTGT \\
\hline & & $\begin{array}{l}\text { Reverse } \\
\text { Probe }\end{array}$ & $\begin{array}{l}225 \text { to } 243 \\
181 \text { to } 209\end{array}$ & $\begin{array}{l}\text { TGCCACTGCCAAGGTCAAC } \\
\text { FAM-TCCATACCTGTAGGACCAAGAGTCCAGCA-TAMRA }\end{array}$ \\
\hline IGF binding protein-2 & $\mathrm{AF} 074854$ & $\begin{array}{l}\text { Forward } \\
\text { Reverse } \\
\text { Probe }\end{array}$ & $\begin{array}{l}765 \text { to } 785 \\
831 \text { to } 850 \\
787 \text { to } 812\end{array}$ & $\begin{array}{l}\text { GCATGGCCTGTACAACCTCAA } \\
\text { TCCCGGTGTTAGGGTTCACA } \\
\text { FAM-CAGTGCAAGATGTCTCTGAACGGGCA-TAMRA }\end{array}$ \\
\hline Cyclophilin A & NM_178320 & $\begin{array}{l}\text { Forward } \\
\text { Reverse } \\
\text { Probe }\end{array}$ & $\begin{array}{l}23 \text { to } 42 \\
65 \text { to } 84 \\
44 \text { to } 63\end{array}$ & $\begin{array}{l}\text { CACCGTGTTCTTCGACATCG } \\
\text { ACAGCTCAAAAGAGACGCGG } \\
\text { VIC-TGTCGACGGCGAGCCCTTGG-TAMRA }\end{array}$ \\
\hline
\end{tabular}

${ }^{1}$ The nucleotide range refers to the GenBank sequence. All sequences are shown $5^{\prime}$ to $3^{\prime}$.

${ }^{2}$ The sequence is not in GenBank but was published by Hauser et al. (1990).

al. (1999) with minor modifications. A $40 \mathrm{~cm}^{2}$ area near the 11th intercostal space on the right side was shaved and disinfected with an iodine scrub solution and $70 \%$ ethanol. Local anesthesia ( $5 \mathrm{~mL}$ of $2 \%$ lidocaine hydrochloride solution) was administered s.c. to desensitize the incision site. A $1 \mathrm{~cm}$-long incision was made at the center of the intercostal space. Liver tissue was collected with a 12-gauge biopsy needle $(15 \mathrm{~cm}$ in length with a $20-\mathrm{mm}$ notch; US Biopsy, Franklin, IN) and was then placed in a screw-cap microcentrifuge tube. The tissue was frozen in liquid $\mathrm{N}$ and stored at $-80^{\circ} \mathrm{C}$ until RNA extraction.

Blood Samples. Blood samples were collected by coccygeal venipuncture at each of the 3 sample collections (before estrus, at estrus, and after estrus). Blood was collected into Vacutainers containing EDTA (BD Vacutainer, Franklin Lakes, NJ) and placed on ice for transport to the laboratory. Plasma was harvested by centrifugation and stored frozen at $-20^{\circ} \mathrm{C}$.

\section{RNA Isolation and Production of cDNA}

Total cellular RNA was isolated from liver and uterine tissue with the Trizol reagent (Invitrogen, Carlsbad, $\mathrm{CA}$ ) according to the instructions of the manufacturer. The uterine samples from each uterine horn were extracted separately. The RNA content of each liver and uterine sample was calculated based on absorbance at $260 \mathrm{~nm}$. The RNA quality was evaluated by calculating the ratio of absorbance at 260 and $280 \mathrm{~nm}$ followed by gel electrophoresis $(0.8 \%$ agarose gel in $0.09 M$ Trisborate and $0.002 M$ EDTA buffer with $0.5 \mu \mathrm{g} / \mathrm{mL}$ of ethidium bromide). The RNA was stored at $-80^{\circ} \mathrm{C}$. Equal amounts of RNA from both uterine horns were combined before reverse transcription, to ensure equal representation of RNA from each uterine horn. The SuperScript First Strand Synthesis System for RT-PCR (Invitrogen) was used to reverse transcribe $2.1 \mu \mathrm{g}$ of RNA to cDNA. The cDNA was stored at $-20^{\circ} \mathrm{C}$ until its use in the reverse transcription PCR (RT-PCR).

\section{Real-Time Quantitative RT-PCR}

Real-time quantitative RT-PCR (Taqman, Applied Biosystems, Foster City, CA) was used to measure the amount of mRNA. Primer (Table 2) and probe sets for the RT-PCR were designed by using the Primer Express Software (Applied Biosystems). The mRNA amounts for total GHR (tGHR), IGF-I, IGFBP-2, and cyclophilin mRNA were measured in liver and uterine samples, whereas the mRNA amounts for GHR1A and histone $\mathrm{H} 2 \mathrm{a}$ were measured in either liver or uterus, respectively. Cyclophilin and histone H2a were initially measured because they were housekeeping gene candidates.

The RT-PCR reactions were prepared as $25-\mu \mathrm{L}$ reactions with $100 \mathrm{n} M$ probe and $500 \mathrm{n} M$ primer using the Brilliant QPCR Plus Core Reagent Kit (Stratagene, La Jolla, CA). A no-template control and 3 internal controls (high, medium, and low mRNA amount) were run in 
triplicate on every 96 -well reaction plate. Samples (25 ng of cDNA) were run in triplicate. The PCR reactions were performed, and fluorescence was quantified with the ABI PRISM 7700 Sequence Detector (Applied Biosystems). Analyses of amplification plots to determine the amplification cycle number at which the fluorescence reached a threshold amount [threshold cycle $\left(\mathbf{C}_{\mathbf{t}}\right)$ ] were performed with the sequence detection software.

The amplification efficiency for each of the target genes was determined by assaying a serial dilution of a single sample (25, 2.5, 0.25, and $0.025 \mathrm{ng}$ of cDNA). Amplification efficiencies were calculated by using the following equation: efficiency $=10^{(-1 / b)}$, where $b=$ the slope of the linear regression of the $\mathrm{C}_{t}$ on the logarithm of the cDNA dose in nanograms of cDNA. The efficiencies for tGHR, GHR1A, IGF-I, IGFBP-2, cyclophilin, and histone $\mathrm{H} 2 \mathrm{a}$ were $2.04,1.98,1.70,1.98,1.68$, and 1.99 with an $R^{2}$ of 0.99 or above for the regression. The fold change for a specific sample was calculated by raising the amplification efficiency to the power of the internal control $\mathrm{C}_{t}$ minus the sample $\mathrm{C}_{\mathrm{t}}$. The fold change for IGF-I, IGFBP-2, tGHR, cyclophilin, and GHR1A was calculated by using a fetal liver sample as the internal control. The fold change for histone H2a was calculated by using an adult liver sample as the internal control sample.

\section{RIA}

Plasma IGF-I concentrations were determined by using RIA assay procedures described previously (Holland et al., 1988). Recombinant human IGF-I was used for iodination and standards (UBI-01-141, Amgen Corp., Thousand Oaks, CA). Antiserum (UB2-495) was provided by the National Hormone and Pituitary Program. Extraction recovery was assessed for concentrations of IGF-I in 2.5-, 5.0-, 7.5-, 10.0-, 25.0-, and 50.0- $\mathrm{LL}$ volumes of serum and was found to equal or exceed $99 \%$. Parallelism was assessed and verified between standard concentrations of IGF-I and serum containing IGF-I in volumes ranging from 2.5 to $50.0 \mu \mathrm{L}$. Concentrations of IGF-I were determined in triplicate aliquots of $40 \mu \mathrm{L}$ of serum samples. Minimum detectability was $0.13 \mathrm{ng} / \mathrm{mL}$. The intraassay CV was $13 \%$.

Plasma estradiol and plasma progesterone were analyzed by validated RIA assay (Kirby et al., 1997). Plasma progesterone concentrations were measured in a single assay with an intraassay $\mathrm{CV}$ of $7 \%$. The intraand interassay $\mathrm{CV}$ for the plasma estradiol assays were 13 and $11 \%$, respectively.

\section{Statistical Analysis}

Uterine mRNA for cyclophilin, IGF-I, tGHR, IGFBP2, and histone $\mathrm{H} 2 \mathrm{a}$ was analyzed for effects of stage of lactation, sample day relative to estrus, pregnancy status, and all 2-way and 3-way interactions. Hepatic cyclophilin, IGF-I, tGHR, IGFBP-2, and GHR1A expression was analyzed for effects of stage of lactation, pregnancy status, and the interaction of stage of lactation and pregnancy status. The analysis was conducted with the mixed models procedure of SAS (PROC MIXED, SAS Institute, Cary, NC). The compound symmetry, unstructured, and autoregressive 1 covariance structures were tested, and the most appropriate covariance structure was used for each analysis. Cow nested within the interaction between stage of lactation and pregnancy status was included in the model as a random effect. Mean separation was performed by using the PDIFF procedure with a Tukey adjustment in SAS. Results are reported as least squares means \pm the standard errors of the least squares means. Correlation analysis was done with PROC CORR of SAS.

\section{RESULTS}

\section{Hormonal, Metabolic, and Gene Expression Changes for Cows at Different Stages of Lactation}

Milk production decreased $(P<0.01)$, but BW $(643 \pm$ $11 \mathrm{~kg})$ and BCS $(2.4 \pm 0.1)$ were similar for cows sampled at different DIM (Table 3$)$. The conception rate $(52 \%$ overall) was not affected by DIM ( $\chi^{2}=4.17$ with $3 \mathrm{df}$ ). Plasma IGF-I concentrations were lowest at 40 DIM $(P$ $<0.06$ ) and increased for cows with greater DIM.

The effects of stage of lactation on gene expression in liver and uterus were small. There was a positive correlation between plasma IGF-I concentrations and liver IGF-I mRNA $\left(\mathrm{R}^{2}=0.43 ; P<0.001\right)$, and the latter variable did not differ relative to DIM. Likewise, liver GHR1A and liver IGFBP-2 mRNA were not affected by DIM. The tGHR amount tended to be lowest at 40 DIM $(P<0.08)$, and cyclophilin mRNA tended to be greatest at 80 DIM $(P<0.06)$.

Uterine gene expression for tGHR, IGFBP-2, and histone H2a was similar for cows with different DIM. There was an effect of stage of lactation on uterine IGFI mRNA $(P<0.05)$ and uterine cyclophilin mRNA $(P<$ 0.06 ), because gene expression was greatest for 80 and 160 DIM (Table 3).

\section{Hormonal and Gene Expression Changes for Cows Around Estrus}

Plasma concentrations of progesterone were greatest $3 \mathrm{~d}$ before estrus (day of $\mathrm{PGF}_{2 \alpha}$ injection), lowest during estrus, and increased again on d 4 after estrus $(P<$ 0.001; Table 4). Plasma concentrations of estradiol and 
Table 3. Plasma IGF-I, liver mRNA, and uterine mRNA (LSM \pm SE) for postpartum dairy cows sampled at $40,80,120$, or $160 \mathrm{DIM}^{1}$

\begin{tabular}{lccccc}
\hline & \multicolumn{5}{c}{ Day of lactation } \\
\cline { 2 - 5 } Item & 40 & 80 & 120 & 160 & $P<^{2}$ \\
\hline Milk production, kg/d & $52 \pm 4$ & $42 \pm 2$ & $38 \pm 3$ & $33 \pm 3$ & 0.01 \\
Conception rate, \% (n) & $80(5)$ & $60(10)$ & $50(10)$ & $25(8)$ & NS $^{3}$ \\
Plasma IGF-I, ng/mL & $38.6 \pm 15.3^{\mathrm{a}}$ & $65.5 \pm 8.8^{\mathrm{ab}}$ & $86.3 \pm 8.6^{\mathrm{b}}$ & $72.8 \pm 10.5^{\mathrm{ab}}$ & 0.06 \\
Liver IGF-I mRNA & $17.2 \pm 7.1$ & $31.2 \pm 4.1$ & $32.4 \pm 4.0$ & $34.1 \pm 5.2$ & NS \\
Liver GHR1A mRNA & $1,030 \pm 755$ & $2,077 \pm 436$ & $1,600 \pm 427$ & $1,719 \pm 551$ & NS \\
Liver tGHR mRNA & $25.4 \pm 7.7^{\mathrm{a}}$ & $49.4 \pm 4.4^{\mathrm{b}}$ & $39.9 \pm 4.3^{\mathrm{ab}}$ & $38.9 \pm 5.6^{\mathrm{ab}}$ & 0.08 \\
Liver IGFBP-2 mRNA & $49.1 \pm 16.5$ & $68.2 \pm 9.5$ & $46.0 \pm 9.3$ & $41.9 \pm 12.0$ & $\mathrm{NS}$ \\
Liver cyclophilin mRNA & $1.58 \pm 0.20^{\mathrm{ab}}$ & $1.95 \pm 0.12^{\mathrm{a}}$ & $1.53 \pm 0.11^{\mathrm{b}}$ & $1.53 \pm 0.15^{\mathrm{b}}$ & 0.06 \\
Uterine IGF-I mRNA & $2.54 \pm 1.49^{\mathrm{ab}}$ & $4.87 \pm 0.86^{\mathrm{ab}}$ & $2.13 \pm 0.84^{\mathrm{b}}$ & $5.17 \pm 0.77^{\mathrm{a}}$ & 0.05 \\
Uterine tGHR mRNA & $0.11 \pm 0.33$ & $0.56 \pm 0.19$ & $0.14 \pm 0.18$ & $0.56 \pm 0.15$ & $\mathrm{NS}$ \\
Uterine IGFBP-2 mRNA & $0.004 \pm 0.03$ & $0.04 \pm 0.02$ & $0.006 \pm 0.02$ & $0.03 \pm 0.01$ & $\mathrm{NS}$ \\
Uterine cyclophilin mRNA & $0.56 \pm 0.18^{\mathrm{ab}}$ & $0.87 \pm 0.11^{\mathrm{a}}$ & $0.50 \pm 0.10^{\mathrm{b}}$ & $0.87 \pm 0.11^{\mathrm{a}}$ & 0.06 \\
Uterine histone H2a mRNA & $0.70 \pm 0.51$ & $1.47 \pm 0.30$ & $0.86 \pm 0.29$ & $1.36 \pm 0.30$ & NS \\
\hline
\end{tabular}

${ }^{\mathrm{a}, \mathrm{b}}$ Means within a row with different superscripts were different at $P<0.05$ unless otherwise noted (Tukey mean separation procedure).

${ }^{1}$ Uterine samples were collected 3 times for each stage (before, during, and after estrus). Liver samples were collected once (after estrus).

${ }^{2} P$-value for the effect of stage of lactation.

${ }^{3}$ Not significant $(P>0.10)$.

${ }^{4}$ The mRNA fold change for a specific sample was calculated by raising the amplification efficiency for an individual gene to the power of the internal control threshold cycle $\left(C_{t}\right)$ minus the sample $C_{t}$. The fold change for IGF-I, IGF binding protein-2 (IGFBP-2), total growth hormone receptor (tGHR), cyclophilin, and growth hormone receptor 1A (GHR1A) was calculated by using a fetal liver sample as the internal control. The fold change for histone $\mathrm{H} 2 \mathrm{a}$ was calculated by using an adult liver sample as the internal control sample.

IGF-I were greatest for cows in estrus $(P<0.001$ and $P<0.003$, respectively) compared with cows before or after estrus.

Because liver samples were collected only after estrus, effects of estrus on liver gene expression were not determined. For uterus (sampled before, during, and after estrus), gene expression was greatest for IGF-I ( $P$ $<0.001)$, tGHR $(P<0.03)$, cyclophilin $(P<0.001)$, and histone $\mathrm{H} 2 \mathrm{a}(P<0.001)$ at estrus compared with before or after estrus. Uterine IGFBP-2 mRNA abundance was numerically greater at estrus but insufficient to achieve statistical significance (effect of day, $P=0.171$ ).

Table 4. Plasma hormone concentrations and uterine mRNA amount (LSM \pm SE) for postpartum dairy cows sampled at 4 stages of lactation (DIM) and at 3 times relative to estrus [approximately $3 \mathrm{~d}$ before (before estrus), during estrus, and $4 \mathrm{~d}$ after estrus (after estrus)]

\begin{tabular}{lcccc}
\hline & \multicolumn{3}{c}{ Sampling time relative to estrus } & \\
\cline { 2 - 4 } Item & $3 \mathrm{~d}$ before estrus & During estrus & $4 \mathrm{~d}$ after estrus & $P<<^{1}$ \\
\hline Plasma progesterone, ng/mL & $4.5 \pm 0.3^{\mathrm{a}}$ & $0.1 \pm 0.1^{\mathrm{c}}$ & $0.7 \pm 0.1^{\mathrm{b}}$ & 0.001 \\
Plasma estradiol, pg/mL & $2.2 \pm 0.3^{\mathrm{a}}$ & $5.2 \pm 0.5^{\mathrm{b}}$ & $2.3 \pm 0.3^{\mathrm{a}}$ & 0.001 \\
Plasma IGF-I, ng/mL & $63.0 \pm 5.9^{\mathrm{a}}$ & $78.6 \pm 7.9^{\mathrm{b}}$ & $55.9 \pm 5.1^{\mathrm{a}}$ & 0.003 \\
Uterine IGF-I mRNA & $1.82 \pm 0.25^{\mathrm{a}}$ & $6.52 \pm 1.02^{\mathrm{b}}$ & $2.70 \pm 0.70^{\mathrm{a}}$ & 0.001 \\
Uterine tGHR mRNA & $0.06 \pm 0.01^{\mathrm{a}}$ & $0.63 \pm 0.20^{\mathrm{b}}$ & $0.34 \pm 0.17^{\mathrm{ab}}$ & 0.03 \\
Uterine IGFBP-2 mRNA & $0.004 \pm 0.001$ & $0.05 \pm 0.03$ & $0.01 \pm 0.01$ & $\mathrm{NS}^{3}$ \\
Uterine cyclophilin mRNA & $0.47 \pm 0.05^{\mathrm{a}}$ & $1.02 \pm 0.10^{\mathrm{b}}$ & $0.62 \pm 0.09^{\mathrm{a}}$ & 0.001 \\
Uterine histone H2a & $0.83 \pm 0.14^{\mathrm{a}}$ & $1.64 \pm 0.29^{\mathrm{b}}$ & $0.82 \pm 0.20^{\mathrm{a}}$ & 0.001 \\
\hline
\end{tabular}

${ }^{\mathrm{a}-\mathrm{c}}$ Means within a row with different superscripts were different at $P<0.05$ (Tukey mean separation procedure).

${ }^{1} P$-value for the effect of sampling time.

${ }^{2}$ The mRNA fold change for a specific sample was calculated by raising the amplification efficiency for an individual gene to the power of the internal control threshold cycle $\left(\mathrm{C}_{t}\right)$ minus the sample $\mathrm{C}_{t}$. The fold change for IGF-I, IGF binding protein-2 (IGFBP-2), total growth hormone receptor (tGHR), and cyclophilin was calculated by using a fetal liver sample as the internal control. The fold change for histone H2a was calculated by using an adult liver sample as the internal control sample.

${ }^{3}$ Not significant $(P>0.10)$. 
Table 5. Plasma IGF-I, liver mRNA, and uterine mRNA amount (LSM \pm SE) for postpartum dairy cows that were pregnant or not pregnant after insemination ${ }^{1}$

\begin{tabular}{lcrc}
\hline & \multicolumn{2}{c}{ Pregnancy status after insemination } & \\
\cline { 2 - 3 } Item & \multicolumn{1}{c}{ Pregnant } & Not pregnant & $P<^{2}$ \\
\hline Milk production, kg/d & $38 \pm 2$ & $44 \pm 2$ & 0.08 \\
Plasma IGF-I, ng/mL & $69.2 \pm 7.0$ & $62.4 \pm 8.7$ & $\mathrm{NS}^{3}$ \\
Liver IGF-I mRNA & $32.8 \pm 3.3$ & $24.7 \pm 4.0$ & $\mathrm{NS}$ \\
Liver GHR1A mRNA & $1,905 \pm 357$ & $1,307 \pm 429$ & $\mathrm{NS}$ \\
Liver tGHR mRNA & $46.5 \pm 3.6$ & $30.2 \pm 4.4$ & 0.01 \\
Liver IGFBP-2 mRNA & $65.3 \pm 7.8$ & $37.2 \pm 9.4$ & 0.03 \\
Liver cyclophilin mRNA & $1.80 \pm 0.09$ & $1.49 \pm 0.11$ & 0.05 \\
Uterine IGF-I mRNA & $3.84 \pm 0.59$ & $3.51 \pm 0.85$ & $\mathrm{NS}$ \\
Uterine tGHR mRNA & $0.44 \pm 0.12$ & $0.24 \pm 0.19$ & $\mathrm{NS}$ \\
Uterine IGFBP-2 mRNA & $0.03 \pm 0.01$ & $0.01 \pm 0.02$ & $\mathrm{NS}$ \\
Uterine cyclophilin mRNA & $0.70 \pm 0.08$ & $0.70 \pm 0.10$ & $\mathrm{NS}$ \\
Uterine histone H2a mRNA & $1.17 \pm 0.21$ & $1.02 \pm 0.29$ & $\mathrm{NS}$ \\
\hline
\end{tabular}

${ }^{1}$ Cows were sampled at 4 different stages of lactation (DIM), and uterine samples were collected 3 times for each DIM (before, during, and after estrus). Liver samples were collected once (after estrus).

${ }^{2} P$-value for the effect of pregnancy status.

${ }^{3}$ Not significant $(P>0.10)$.

${ }^{4}$ The mRNA fold change for a specific sample was calculated by raising the amplification efficiency for an individual gene to the power of the internal control threshold cycle $\left(\mathrm{C}_{t}\right)$ minus the sample $\mathrm{C}_{t}$. The fold change for IGF-I, IGF binding protein-2 (IGFBP-2), total growth hormone receptor (tGHR), cyclophilin, and growth hormone receptor 1A (GHR1A) was calculated by using a fetal liver sample as the internal control. The fold change for histone H2a was calculated by using an adult liver sample as the internal control sample.

\section{Gene Expression in Pregnant vs. Nonpregnant Cows}

Seventeen cows became pregnant, and 16 cows remained nonpregnant after insemination (Table 3). Milk production tended to be lower among cows that became pregnant (Table 5). Liver tGHR $(P<0.01)$, IGFBP-2 $(P$ $<0.03)$, and cyclophilin mRNA $(P<0.05)$ were greater among pregnant vs. nonpregnant cows, whereas liver GHR1A and IGF-I mRNA were similar. Within liver, there were no interactions of DIM with pregnancy status for the genes that were tested. Uterine gene expression (IGF-I, tGHR, IGFBP-2, cyclophilin, and histone H2a mRNA) was similar for pregnant and nonpregnant cows, and there were no interactions with day of tissue sampling relative to estrus or DIM.

\section{Correlations}

Abundance of uterine mRNA (IGF-I, tGHR, IGFBP2, histone $\mathrm{H} 2 \mathrm{a}$, and cyclophilin) was subjected to crosscorrelation analysis (correlation coefficients $>0.6$ with $P<0.001$; Table 6). Extremely high correlations existed between uterine IGF-I and uterine cyclophilin (Figure 1A) and uterine IGF-I and tGHR (Figure 1B). Correlation coefficients for pairs of liver-expressed genes were also significant (Table 6). Most correlations for specific mRNA expressed in liver and the same or different mRNA expressed in uterus were not significant, with the exception of liver IGFBP-2, which was moderately correlated with the abundance of mRNA for IGF-I, tGHR, IGFBP-2, histone H2a, and cyclophilin in uterus (Table 6).

\section{DISCUSSION}

Liver and uterine tissues were biopsied from dairy cows at different stages of lactation to determine if hepatic or uterine gene expression changed with DIM. Samples were also collected at different times around estrus (before estrus, estrus, and $4 \mathrm{~d}$ after estrus). We found that DIM had a small effect on hepatic and uterine gene expression, whereas time of sampling relative to estrus had a large effect. Cows that were pregnant vs. not pregnant after insemination were similar in terms of uterine gene expression but differed relative to expression of specific genes in liver. We suggest that the metabolic status of the cow, and thus response by the liver, may have a greater role in insemination outcome (pregnant vs. not pregnant) than uterine IGF system genes that we tested.

In this study, amplification plots were used to determine the amplification cycle number at which the fluorescence reached a threshold amount $\left(\mathrm{C}_{t}\right)$. The true amplification efficiency for each of the target genes was also determined by assaying a serial dilution of a single sample. The efficiencies were all nearly equivalent to 2.0 , and this indicates that there was a 2 -fold increase in DNA with each amplification cycle. The fold change 
Table 6. Pearson correlation coefficients for the amount of mRNA in either uterus or liver ${ }^{1}$

\begin{tabular}{llllllr}
\hline & & \multicolumn{5}{c}{ mRNA $^{2}$} \\
\cline { 3 - 6 } Tissue & mRNA $^{3}$ & IGF-I & IGFBP2 & tGHR & GHR1A $^{4}$ & Cyclophilin \\
\hline Uterus & HH2a & $0.72^{* * * *}$ & $0.74^{* * *}$ & $0.64^{* * *}$ & - & $0.74^{* * * *}$ \\
Uterus & Cyclophilin & $0.91^{* * *}$ & $0.62^{* * *}$ & $0.75^{* * *}$ & - & \\
Liver & Cyclophilin & 0.19 & 0.19 & $0.59^{* * *}$ & $0.33 \dagger$ & \\
Liver & GHR1A & $0.43^{* * *}$ & 0.18 & $0.72^{* * *}$ & \\
Uterus & tGHR & $0.82^{* * *}$ & $0.84^{* * *}$ & & \\
Liver & tGHR & $0.67^{* * *}$ & $0.38^{*}$ & & \\
Uterus & IGFBP-2 & $0.71^{* * *}$ & & & \\
Liver & IGFBP-2 & 0.25 & & & \\
Liver & IGFBP-2 & $0.43^{* *}$ & $0.54^{* *}$ & $0.56^{* * *}$ & - & $0.54^{* * *}$ \\
\hline
\end{tabular}

${ }^{1}$ The amount of a specific mRNA in either tissue was correlated with a different mRNA in the same tissue (first 8 rows) or with a different mRNA in uterus (last row, liver IGF binding protein-2 (IGFBP-2) was correlated with uterine mRNA).

${ }^{2}$ Pearson correlation coefficient for the regression of the first mRNA on the second mRNA within a single tissue (first eight rows) or across 2 tissues (last row).

${ }^{3} \mathrm{HH} 2 \mathrm{a}=$ histone $\mathrm{H} 2 \mathrm{a}$; tGHR = total growth hormone receptor.

${ }^{4}$ The growth hormone receptor 1A (GHR1A) mRNA is not expressed in uterus and was not measured in uterine tissues within this study. A correlation coefficient, therefore, could not be calculated for uterine GHR1A.

${ }^{5}$ Correlation coefficients are for liver IGFBP-2 and uterine mRNA.

$* P<0.05 ; * * P<0.01 ; * * * P<0.001 ; \dagger P<0.10$.

for a specific sample was calculated by raising the amplification efficiency to the power of the $\Delta \mathrm{C}_{\mathrm{t}}$, where the $\Delta \mathrm{C}_{\mathrm{t}}$ was the $\mathrm{C}_{\mathrm{t}}$ of an internal control sample minus the $\mathrm{C}_{\mathrm{t}}$ of our test sample. The internal control was an identical sample that was included in every assay plate (i.e., the internal control was used to standardize results across assay plates). Cyclophilin and histone $\mathrm{H} 2 \mathrm{a}$ were evaluated as potential housekeeping (reference) genes, but neither was suitable in our minds for this purpose. There were significant main effects when the expression of each was tested. The data that we present, therefore, are unadjusted for a housekeeping gene (i.e., the data are fold differences expressed as a deviation from the control sample that was run on every assay plate). Although the possibility of adjusting data for a housekeeping gene is appealing, the danger in doing so is that the selected housekeeping gene and the target gene will undergo coordinate regulation. If true, then adjusting for the housekeeping gene will obscure relevant changes in the gene of interest.

The sample times that we chose (40 to $160 \mathrm{DIM}$ ) enabled us to examine gene expression around the time of AI. We excluded the early postpartum period $(<20$ DIM), because inseminated cows would have low fertility. The samples that were taken ( 40 to $160 \mathrm{DIM}$ ), therefore, did not include the early postpartum period when there are major changes in GH-IGF system (Lucy et al., 2001). Cows become refractory to GH after calving through a mechanism that involves the downregulation of GHR mRNA expression. The loss of the GHR leads to decrease IGF-I in postpartum cows (Radcliff et al.,
2003). The GH-IGF system recouples in postpartum cows when GHR mRNA increases. Greater GHR leads to more IGF-I synthesis and secretion (Radcliff et al., 2004). Presumably, cows in this study underwent the transient changes in the GH-IGF-I system that typifies postpartum cows. The recoupling was incomplete, however, because plasma IGF-I concentrations increased after 40 DIM, suggesting the cows at 40 DIM had not fully reestablished their GH-IGF-I system relative to later postpartum cows in this study.

The increase in liver IGF-I mRNA after 40 DIM was not significant, but there was a positive correlation between plasma IGF-I and liver IGF-I mRNA. This relationship has been observed before (Le Roith et al., 2001; Lucy et al., 2001) and supports the idea that most of the IGF-I in blood arises from liver IGF-I synthesis and secretion. Total GHR mRNA amount increased after 40 DIM as well. Changes in GHR1A mRNA (liver-specific GHR transcript) underwent a nonsignificant increase after $40 \mathrm{DIM}$, and there was a high correlation between tGHR and GHR1A mRNA. The general conclusion from the results of the liver GHR and IGF-I analysis is that cows after 40 DIM have greater GHR and IGF-I expression. The increase in GHR and IGF-I may reflect improved energy balance because of lesser milk production and greater DMI. Increased IGF-I expression leads to an increase in plasma IGF-I concentrations.

We chose to measure IGFBP-2 in lieu of other IGFBP that could have been studied. Insulin-like growth factor binding protein-2 is expressed throughout the bovine reproductive tract (Kirby et al., 1996; Wathes et al., 

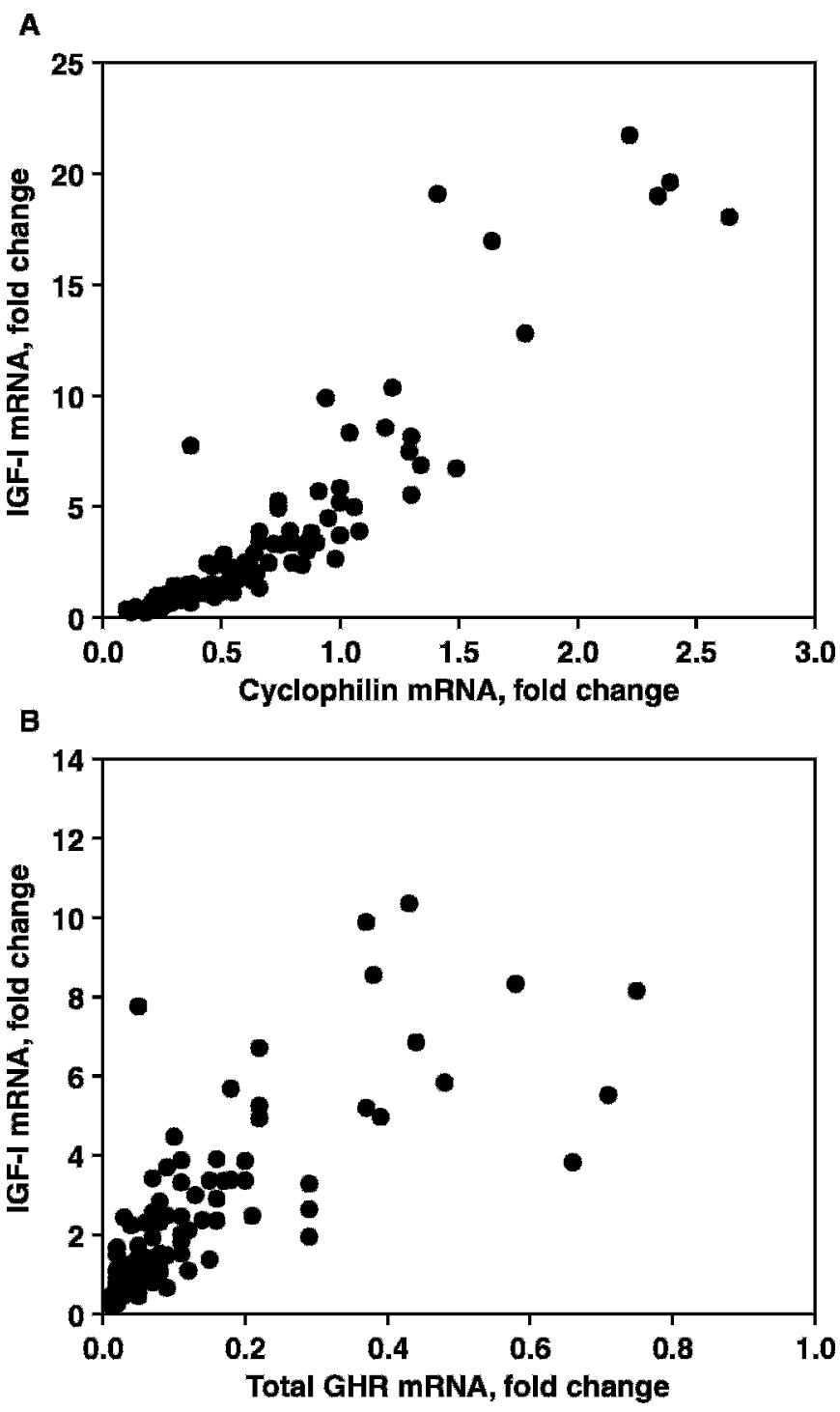

Figure 1. Regression of fold change for IGF-I mRNA on fold change for cyclophilin mRNA (A: IGF-I $=8.4 \times$ cyclophilin $-2.1 ; \mathrm{R}^{2}=0.82$, $P<0.001$ ) or fold change for total growth hormone receptor mRNA [B: $\mathrm{IGF}-\mathrm{I}=4.9 \times$ growth hormone receptor $(\mathrm{GHR})+2.2 ; \mathrm{R}^{2}=0.68$, $P<0.001]$ in uterine biopsy samples collected from postpartum dairy cows at $40,80,120$, or 160 DIM.

1998). Within the bovine uterus, IGFBP-2 is expressed in the subepithelial stroma (Robinson et al., 2000). Our biopsies should have included this region of the uterus that is adjacent to the luminal epithelium. During early lactation, circulating IGFBP-2 concentrations are typically elevated (Vicini et al., 1991; Sharma et al., 1994). The concentrations of IGFBP-2 increase during undernutrition as well in both heifers (Vandehaar et al., 1995) and lambs (Rhoads et al., 2000). Based on these collective responses, we viewed the measurement of IGFBP2 as relevant to our work. When measured in this study, however, DIM did not affect IGFBP-2 expression in liver or uterus. Our failure to observe a change may be related to our sampling time (40 to $160 \mathrm{DIM}$ ) that was after the period when large changes in blood IGFBP-2 are known to occur in cattle (Vicini et al., 1991; Sharma et al., 1994).

Uterine gene expression for GHR and IGF-I was not duplicative of liver gene expression. Uterine IGF-I expression was lowest at $120 \mathrm{DIM}$ and greatest at 160 DIM. The change in uterine IGF-I expression from 120 to 160 DIM was statistically significant, but we know of no physiological basis for such a change to occur at these DIM. Changes in GHR expression were not significant. The important implication from these data is that gene expression across tissues (in this case liver and uterus) is not coordinately regulated in postpartum dairy cows. Thus, the metabolic factors that control GHR and IGF-I in liver must not congruently control GHR and IGF-I in uterus. This conclusion was supported by our observation that gene expression data from liver and uterine tissue sampled from the same cow and at the same time were generally not correlated (Table 6). The only exception was the expression of liver IGFBP-2 mRNA, which was moderately correlated with uterine mRNA expression (subsequently mentioned).

There were large changes in uterine gene expression during estrus. Every gene that we tested underwent a significant or numeric (IGFBP-2) increase from the time of $\mathrm{PGF}_{2 \alpha}$ injection (luteal phase) to estrus. Most changes in gene expression were moderate (2- to 3 -fold increase), but some were large (10-fold increase, tGHR). In most cases, gene expression returned to basal levels by $4 \mathrm{~d}$ after estrus with the exception of tGHR, which remained elevated. Estrus was associated with greater plasma IGF-I, presumably arising from liver IGF-I gene expression, but we cannot confirm this, because liver was only sampled $4 \mathrm{~d}$ after estrus.

The increase in tGHR at estrus may have increased uterine sensitivity to $\mathrm{GH}$, and the greater $\mathrm{GH}$ sensitivity may have increased GH-dependent IGF-I synthesis. Alternatively, both tGHR and IGF-I gene expression in the uterus may be controlled by a common mechanism. In either case, the previously mentioned changes in gene expression are probably dependent on estradiol from the preovulatory follicle. The increase in uterine IGF-I mRNA at estrus agrees with the finding of a previous study conducted by Meikle et al. (2001). Wathes et al. (1998) also found greater IGF-I secretion into the uterine lumen at estrus. The greater IGF-I at estrus may increase uterine secretory activity and thereby enhance the uterine environment for embryonic development (Robinson et al., 2000). Indeed, previous studies have demonstrated increased pregnancy 
rates when bST was administered at AI, thereby increasing plasma IGF-I concentrations (Morales-Roura et al., 2001; Santos et al., 2004).

The increase in cyclophilin and histone H2a expression at estrus provides evidence that proliferative changes are occurring in endometrium, presumably in response to estradiol. In ewes, a single estradiol injection upregulates uterine cyclophilin mRNA by 45 to 100\% (Robertson et al., 2001; Farnell and Ing, 2003a,b). Likewise, estradiol treatment of gilts increased endometrial histone H2a mRNA concentrations by 9 - to 10 fold (Cardenas and Pope, 2004).

Later postpartum inseminations and greater IGF-I concentrations were associated with improved fertility in lactating dairy cows (Moreira et al., 2000, 2001; Morales-Roura et al., 2001; Santos et al., 2004; Bilby et al., 2006). Within this experiment, therefore, we expected that conception rates would improve for later lactation cows. In this study, however, late lactation cows (160 DIM) had the lowest conception rate (25\%), whereas very early lactation cows (40 DIM) had the highest conception rate $(80 \% ; \mathrm{n}=5)$. This experiment was not designed to test conception rate, and we believe that these nonsignificant differences were a consequence of relatively small animal numbers. The high overall conception rate $(52 \%)$ lends evidence that the uterine biopsy procedure did not adversely affect the establishment of pregnancy.

Uterine gene expression was similar for cows that were pregnant or not pregnant following insemination. This observation is important, because it suggests that the amount of expression for IGF-I system genes in uterus does not affect the likelihood of pregnancy in the dairy cow. Perhaps alternative systems override the potential stimulatory effects of IGF-I on the embryo and uterus. A second possibility is that our analyses did not include an essential component of the IGF-I system. For example, the IGF receptor itself or some component of the IGF signaling cascade may be limiting in cows that do not become pregnant after insemination. Analyses of the IGF signaling cascade are difficult, because mRNA, protein, and phosphorylation states of proteins must be examined to fully characterize the functional aspects of the system. This work was beyond the focus of the present study.

Although gene expression within uterus was similar, differences in gene expression for pregnant and nonpregnant cows were observed within the liver. Cows that were pregnant after insemination had greater tGHR and IGFBP-2 mRNA than cows that did not become pregnant (Table 5). Although the difference was not significant, hepatic IGF-I and plasma IGF-I concentrations were numerically greater in cows that became pregnant than cows that did not become pregnant. This observation agrees with the results of a previous experiment in which dairy cows with higher blood IGF-I concentrations (over $50 \mathrm{ng} / \mathrm{mL}$ ) had a 5 -fold increase in pregnancy rate (Taylor et al., 2004). Cows that became pregnant also tended to produce less milk than cows that did not become pregnant $(P<0.08)$. One interpretation of these data is that the cows that became pregnant were producing less milk, and thus their lower milk production was associated with elevated GHR. The shift toward greater GHR implies improved sensitivity within the somatotropic axis (indicative of more positive energy balance). Collectively, the implications are that improved metabolic status of the cow, as evidenced by hepatic gene expression, increased the likelihood of pregnancy.

We found a high correlation among our estimates of gene expression across cows. Some of the correlations were expected (i.e., a correlation between GHR and IGF-I gene expression), whereas others were surprising. For example, the $\mathrm{R}^{2}$ for IGF-I and cyclophilin mRNA in uterus was greater than 0.80 (Figure 1A). Correlations in gene expression in uterus were generally higher than those found for liver. This observation may reflect the more diverse nature of liver sampling (proximal vs. distal portions of the lobe, etc.) compared with uterine endometrium or may be explained by the greater number of endometrial samples analyzed. The observed correlations in gene expression imply that individual cows have relatively high or relatively low expression for multiple genes. The abundance of expression for a single gene may reflect global mechanisms that control the expression of numerous genes. In this study, correlations in gene expression were not the product of a simple or single variable function, specifically the occurrence of estrus. Hence, uterine gene expression correlations remained significant irrespective of estrus (data not shown). Across tissues (liver and uterus), liver IGFBP-2 and each of the uterine genes were correlated. Although these correlations were small, they were nonetheless significant and were only found for liver IGFBP-2. The implication is that the mechanisms that control IGFBP-2 in liver may also control the expression of several genes in uterus.

\section{CONCLUSIONS}

Liver and uterine tissues were sampled from dairy cows to determine the effects of DIM, stage of the estrous cycle, and insemination outcome (pregnant vs. not pregnant) on hepatic and uterine GH-IGF system gene expression. Days in milk had a small effect on hepatic and uterine gene expression. Time of sampling relative to estrus (stage of estrous cycle) had a large effect on hepatic and uterine gene expression. Cows 
that were pregnant vs. not pregnant after insemination were similar in terms of uterine gene expression but differed relative to expression of genes in liver. The metabolic status of the cow (reflected in hepatic gene expression) was more predictive of the likelihood of pregnancy than the local uterine synthesis of IGF system genes.

\section{REFERENCES}

Bilby, T. R., A. Sozzi, M. M. Lopez, F. T. Silvestre, A. D. Ealy, C. R. Staples, and W. W. Thatcher. 2006. Pregnancy, bovine somatotropin, and dietary n-3 fatty acids in lactating dairy cows. I. Ovarian, conceptus, and growth hormone-insulin-like growth factor system responses. J. Dairy Sci. 89:3360-3374.

Borman, J. M., R. P. Radcliff, B. L. McCormack, F. N. Kojima, D. J. Patterson, K. L. Macmillan, and M. C. Lucy. 2003. Synchronisation of oestrus in dairy cows using prostaglandin $\mathrm{F}_{2 \alpha}$, gonadotrophin-releasing hormone, and oestradiol cypionate. Anim. Reprod. Sci. 76:163-176.

Cardenas, H., and W. F. Pope. 2004. Attenuation of estrogenic effects by dihydrotestosterone in the pig uterus is associated with downregulation of the estrogen receptors. Biol. Reprod. 70:297-302.

Farnell, Y. Z., and N. H. Ing. 2003a. Endometrial effects of selective estrogen receptor modulators (SERMs) on estradiol-responsive gene expression are gene and cell-specific. J. Steroid Biochem. Mol. Biol. 84:513-526.

Farnell, Y. Z., and N. H. Ing. 2003b. Myometrial effects of selective estrogen receptor modulators on estradiol-responsive gene expression are gene and cell-specific. J. Steroid Biochem. Mol. Biol. 84:527-536.

Hauser, S. D., M. F. McGrath, R. J. Collier, and G. G. Krivi. 1990. Cloning and in vivo expression of bovine growth hormone receptor mRNA. Mol. Cell. Endocrinol. 72:187-200.

Holland, M. D., K. L. Hossner, G. D. Niswender, T. H. Elsasser, and K. G. Odde. 1988. Validation of a heterologous radioimmunoassay for insulin-like growth factor-I in bovine serum. J. Endocrinol. 119:281-285.

Izadyar, F., B. Colenbrander, and M. M. Bevers. 1996. In vitro maturation of bovine oocytes in the presence of growth hormone accelerates nuclear maturation and promotes subsequent embryonic development. Mol. Reprod. Dev. 45:372-377.

Kirby, C. J., M. F. Smith, D. H. Keisler, and M. C. Lucy. 1997. Follicular function in lactating dairy cows treated with sustainedrelease bovine somatotropin. J. Dairy Sci. 80:273-285.

Kirby, C. J., W. W. Thatcher, R. J. Collier, F. A. Simmen, and M. C. Lucy. 1996. Effects of growth hormone and pregnancy on expression of growth hormone receptor, insulin-like growth factor-I, and insulin-like growth factor binding protein-2 and -3 genes in bovine uterus, ovary, and oviduct. Biol. Reprod. 55:996-1002.

Kobayashi, Y., C. K. Boyd, C. J. Bracken, W. R. Lamberson, D. H. Keisler, and M. C. Lucy. 1999. Reduced growth hormone receptor (GHR) messenger ribonucleic acid in liver of periparturient cattle is caused by a specific down-regulation of GHR1A that is associated with decreased insulin-like growth factor I. Endocrinology 140:3947-3954.

Leon, H. V., J. Hernandez-Ceron, D. H. Keisler, and C. G. Gutierrez. 2004. Plasma concentrations of leptin, insulin-like growth factor$\mathrm{I}$, and insulin in relation to changes in body condition score in heifers. J. Anim. Sci. 82:445-451.

Le Roith, D., C. Bondy, S. Yakar, J. L. Liu, and A. Butler. 2001. The somatomedin hypothesis: 2001. Endocr. Rev. 22:53-74.

Lucy, M. C., H. Jiang, and Y. Kobayashi. 2001. Changes in the somatotrophic axis associated with the initiation of lactation. J. Dairy Sci. 84:E113-E119.

McGuire, M. A., D. E. Bauman, D. A. Dwyer, and W. S. Cohick. 1995. Nutritional modulation of the somatotropin/insulin-like growth factor system: Response to feed deprivation in lactating cows. J. Nutr. 125:493-502.
Meikle, A., L. Sahlin, A. Ferraris, B. Masironi, J. E. Blanc, M. Rodriguez-Irazoqui, M. Rodriguez-Pinon, H. Kindahl, and M. Forsberg. 2001. Endometrial mRNA expression of oestrogen receptor $\alpha$, progesterone receptor and insulin-like growth factor-I (IGF-I) throughout the bovine oestrous cycle. Anim. Reprod. Sci. 68:45-56.

Morales-Roura, J. S., L. Zarco, J. Hernandez-Ceron, and G. Rodriguez. 2001. Effect of short-term treatment with bovine somatotropin at estrus on conception rate and luteal function of repeatbreeding dairy cows. Theriogenology 55:1831-1841.

Moreira, F., L. Badinga, C. Burnley, and W. W. Thatcher. 2002a. Bovine somatotropin increases embryonic development in superovulated cows and improves post-transfer pregnancy rates when given to lactating recipient cows. Theriogenology 57:1371-1387.

Moreira, F., C. Orlandi, C. A. Risco, R. Mattos, F. Lopes, and W. W. Thatcher. 2001. Effects of presynchronization and bovine somatotropin on pregnancy rates to a timed artificial insemination protocol in lactating dairy cows. J. Dairy Sci. 84:1646-1659.

Moreira, F., F. F. Paula-Lopes, P. J. Hansen, L. Badinga, and W. W. Thatcher. 2002b. Effects of growth hormone and insulin-like growth factor-I on development of in vitro derived bovine embryos. Theriogenology 57:895-907.

Moreira, F., C. A. Risco, M. F. Pires, J. D. Ambrose, M. Drost, and W. W. Thatcher. 2000. Use of bovine somatotropin in lactating dairy cows receiving timed artificial insemination. J. Dairy Sci. 83:1237-1247.

Radcliff, R. P., B. L. McCormack, B. A. Crooker, and M. C. Lucy. 2003. Plasma hormones and expression of growth hormone receptor and insulin-like growth factor-I mRNA in hepatic tissue of periparturient dairy cows. J. Dairy Sci. 86:3920-3926.

Radcliff, R. P., M. J. VandeHaar, Y. Kobayashi, B. K. Sharma, H. A. Tucker, and M. C. Lucy. 2004. Effect of dietary energy and somatotropin on components of the somatotropic axis in Holstein heifers. J. Dairy Sci. 87:1229-1235.

Rausch, M. I., M. W. Tripp, K. E. Govoni, W. Zang, W. J. Weber, B. A. Crooker, T. A. Hoagland, and S. A. Zinn. 2002. The influence of level of feeding on growth and serum insulin-like growth factor I and insulin-like growth factor-binding proteins in growing beef cattle supplemented with somatotropin. J. Anim. Sci. 80:94-100.

Rhoads, R. P., P. L. Greenwood, A. W. Bell, and Y. R. Boisclair. 2000. Nutritional regulation of the genes encoding the acid-labile subunit and other components of the circulating insulin-like growth factor system in the sheep. J. Anim. Sci. 78:2681-2689.

Robertson, J. A., Y. Zhang, and N. H. Ing. 2001. ICI 182,780 acts as a partial agonist and antagonist of estradiol effects in specific cells of the sheep uterus. J. Steroid Biochem. Mol. Biol. 77:281-287.

Robinson, R. S., G. E. Mann, T. S. Gadd, G. E. Lamming, and D. C. Wathes. 2000. The expression of the IGF system in the bovine uterus throughout the oestrous cycle and early pregnancy. J. Endocrinol. 165:231-243.

Santos, J. E., S. O. Juchem, R. L. Cerri, K. N. Galvao, R. C. Chebel, W. W. Thatcher, C. S. Dei, and C. R. Bilby. 2004. Effect of bST and reproductive management on reproductive performance of Holstein dairy cows. J. Dairy Sci. 87:868-881.

Sharma, B. K., M. J. Vandehaar, and N. K. Ames. 1994. Expression of insulin-like growth factor-I in cows at different stages of lactation and in late lactation cows treated with somatotropin. J. Dairy Sci. 77:2232-2241.

Starbuck, M. J., E. K. Inskeep, and R. A. Dailey. 2006. Effect of a single growth hormone (rbST) treatment at breeding on conception rates and pregnancy retention in dairy and beef cattle. Anim. Reprod. Sci. 93:349-359.

Taylor, V. J., Z. Cheng, P. G. Pushpakumara, D. E. Beever, and D. C. Wathes. 2004. Relationships between the plasma concentrations of insulin-like growth factor-I in dairy cows and their fertility and milk yield. Vet. Rec. 155:583-588.

Thissen, J. P., J. M. Ketelslegers, and L. E. Underwood. 1994. Nutritional regulation of the insulin-like growth factors. Endocr. Rev. 15:80-101.

Vandehaar, M. J., B. K. Sharma, and R. L. Fogwell. 1995. Effect of dietary energy restriction on the expression of insulin-like growth 
factor-I in liver and corpus luteum of heifers. J. Dairy Sci. 78:832-841.

Vicini, J. L., F. C. Buonomo, J. J. Veenhuizen, M. A. Miller, D. R. Clemmons, and R. J. Collier. 1991. Nutrient balance and stage of lactation affect responses of insulin, insulin-like growth factors I and II, and insulin-like growth factor-binding protein 2 to somatotropin administration in dairy cows. J. Nutr. 121:1656-1664.
Wathes, D. C., T. S. Reynolds, R. S. Robinson, and K. R. Stevenson. 1998. Role of the insulin-like growth factor system in uterine function and placental development in ruminants. J. Dairy Sci. 81:1778-1789.

Watson, A. J., M. E. Westhusin, and Q. A. Winger. 1999. IGF paracrine and autocrine interactions between conceptus and oviduct. J. Reprod. Fertil. Suppl. 54:303-315. 